\title{
An evaluation of the adsorption process in removing organic substances in a pilot flow-type surface water treatment system
}

\author{
Matgorzata Wolska ${ }^{1,2,{ }^{*}, \text { Marek Mołczan }}{ }^{1,2}$, Stawomir Szerzyna ${ }^{1}$, Wojciech Adamski ${ }^{1}$, Jacek Wiśniewski ${ }^{1}$, Zbigniew Ferenc $^{1}$, \\ Aleksandra Sambor ${ }^{1}$, and Matgorzata Żółtowska ${ }^{2}$ \\ ${ }^{1}$ The Department of Water and Sewage Treatment Technology, Wrocław University of Science and Technology, Wybrzeże \\ Wyspiańskiego 27 Street, 50-370 Wrocław, Poland \\ ${ }^{2}$ Municipal Water and Sewerage Company in Wrocław, Na Grobli 14/16 Street, 50-421 Wrocław, Poland
}

\begin{abstract}
This article presents the results of the adsorption process effectiveness in treating surface water, especially in removing organic substances. The effectiveness of the adsorption system was evaluated at different levels of adsorption capacity exhaustion of the activated carbon bed, which was possible due to replacement of the beds during the study period. Studies have shown that among the removed substances, chlorinated disinfection byproduct precursors dominated, and during the period preceding bed replacement, the biological activity of microorganism populating the activated carbon ensured a reduction in not only organic but also non-organic food substrates. In such a adsorption bed populated with microorganism a nitrification process took place, indicating a high degree of process stability. Replacing the adsorption beds provided a significant increase in the effectiveness of removing organic substances, especially those absorbing UV light, therefore removing chlorinated organic disinfection by-product precursors.
\end{abstract}

\section{Introduction}

The increase in contamination of source surface waters due to their contamination with household and industrial wastewater and atmospheric precipitation has caused that water treatment systems more often make use of adsorption processes [1,2]. This process ensures the removal of organic substances of medium and low molecular mass [3-7], whose elimination is not possible during the coagulation process, which is commonly used for removing organic substances from surface waters before the adsorption process. Additionally, as many studies show [8,9], adsorption of activated carbon allows for a elimination of various types of microcontaminants. More frequently, different groups of microcontaminants are detected in waters, and within these groups a constantly increasing number of chemical compounds being introduced into the environment. The adsorption process effectively removes some pharmaceuticals [10], pesticides [11], phenols [12] and non-organic microcontaminants such as heavy metals [13]. This is one of the reasons of the increasing use of activated carbon in surface water treatment technology.

Surface water treatment technology also commonly makes use of that fact that adsorption beds are easily populated with microorganisms, which form a biofilm on the bed surface $[14,15]$. Biologically activated beds yield an increase in organic substance removal due to biodegradation by microorganisms. [16]. An increase in the effectiveness of biologically active beds in removing organic substances is also achieved by preceding adsorption process with ozonation [8] which yields a change in the structure of organic substances in water towards one more susceptible to adsorption and biodegradation.

The effectiveness of adsorption depends on many factors and decreases along with increasing bed operating time, and therefore the exhausting of adsorbent potential. . Generally, in technical-scale systems, the need for bed replacement/regeneration is decided by, apart from worsening of filtrate quality, by the iodine number value

The study presented in this paper was conducted at a pilot scale in a flow-type system supplied by a surface water treatment plant, which allowed for an evaluation of the changes of the adsorption process efficiency with changes in raw water quality in conditions of continuous and long-term operation.

\section{Methods of study}

Studies of adsorption process effectiveness in the surface water treatment system were conducted in a pilot-scale flow-type system with a throughput of $3 \mathrm{~m}^{3} / \mathrm{h}$ consisting of coagulation, sedimentation, filtration, adsorption, disinfection and $\mathrm{pH}$ correction. The treatment system was 
supplied with the same water as the water treatment plant treating water for human consumption. The adsorption process was conducted in the system in pressure filters with a bed with granulated activated carbon, whose properties are shown in Table 1.

Table 1. Parameters of fresh WG-12 activated carbon.

\begin{tabular}{|c|c|c|c|}
\hline No & Parameter & Unit & Value \\
\hline 1. & Bulk density & $\mathrm{g} / \mathrm{dm}^{3}$ & 470 \\
\hline 2 & Volatile content & $\%$ & 1.50 \\
\hline 3 & Ash Content & $\%$ & 11.6 \\
\hline 4. & Specific Surface Area & $\mathrm{m}^{2} / \mathrm{g}$ & 968 \\
\hline 5. & Iodine Number $*$ & $\mathrm{mg} / \mathrm{g}$ & 1014 \\
\hline 6. & CTC -adsorption CCI 4 & $\%$ & 62.30 \\
\hline 7. & $\begin{array}{c}<0,5 \text { mm subfraction } \\
\text { content }\end{array}$ & $\%$ & 0.00 \\
\hline 8. & Mechanical strength & $\%$ & 97.30 \\
\hline
\end{tabular}

$*_{\text {value specified by manufacturer of fresh activated carbon }}$

The beds were filled in June 2016, and were replaced in September 2016, which makes it possible to evaluate the effectiveness of the adsorption process in different phases of bed adsorption capacity exhaustion. During the bed replacement, an analysis of the iodine number of the bed being removed was performed, which yielded a value of $660 \mathrm{mg} / \mathrm{g}$, which indicated that the adsorbing potential of this bed had not yet been exhausted. This same value for the fresh bed was $1040 \mathrm{mg} / \mathrm{g}$.

Despite operation the system at a constant throughput, the adsorption filters were operated at varying operating parameters, which resulted from the necessity of continuous system operation (Table 2).

Table 2. Adsorption bed operating parameters.

\begin{tabular}{|c|c|c|}
\hline Parameter & Unit & Value \\
\hline Filtration area & $\mathrm{m}^{2}$ & 0.59 \\
\hline Bed height & $\mathrm{m}$ & 1.50 \\
\hline Filtration Rate & $\mathrm{m} / \mathrm{h}$ & $4.71-5.15$ \\
\hline $\begin{array}{c}\text { Water-Activated Carbon } \\
\text { Contact Time }\end{array}$ & $\mathrm{min}$ & $17.40-19.0$ \\
\hline
\end{tabular}

The study was conducted during the time period from May 2016 to December 2016, with samples being taken weekly before and after the adsorption process. The long time period of the study, and therefore the large variation in raw water, allowed for assessment of the impact of supply water quality on the adsorption process effectiveness.

In all water samples, the following parameters were measured: $\mathrm{T}, \mathrm{pH}$, specific conductivity, color, turbidity,
UV absorbance $\mathrm{UV}_{254}$ and $\mathrm{UV}_{272}$, total (TOC) and dissolved (DOC) organic carbon concentration, nonorganic nutrient concentrations (ammonia ion, nitrites, nitrates, phosphates) and concentrations of chlorides and sulfates. In all pre- and post-adsorption water samples, the total psychrophillic and mesophillic bacteria numbers were also determined.

Based on $\mathrm{UV}_{254}$ absorbance values, and DOC concentrations the specific UV absorbance values (SUV-a) was calculated.

All analysis of water quality indicators were conducted with current Polish standards, according to accredited laboratory procedures.

\section{Results and discussion}

The source water quality during the study period was characterized by a very large variability in composition, which consequently resulted in a decrease in quality of water undergoing adsorption (Table 3 ). The variability in composition was however lower in water before adsorption than that found for raw water. This means that the coagulation process used before adsorption, along with sedimentation, ensured an effective elimination of organic substances and significantly reduced the variability of water quality reaching the adsorption beds [17].

The greatest variability in water reaching the adsorption filters, apart from temperature, was found for indicators relating to organic substance content (TOC, DOC, $\mathrm{UV}_{254}$ and $\mathrm{UV}_{272}$ absorbances and color). Among the organic substances in water supplying adsorption beds, the dissolved fraction dominated (from $96.9 \%$ to $99.1 \%$ ), which testifies to the large susceptibility of organic substances to removal by adsorption. Furthermore, the calculated SUV-a values in the range of $1.65-2.20 \mathrm{~m}^{2} / \mathrm{g}$ testify to the limited susceptibility of organic substances to removal during this process [18].

The presence of non-organic nutrient substrates in water supplying the beds (Table 3) and microorganisms which may allow for biofilm development (Fig. 1), along with the long adsorption bed operating time suggest the conclusion that, apart from adsorption, biodegradation also took place within the beds.

The effectiveness of the adsorption process is confirmed by the elimination of organic substances that was found, which during the study was in the ranges of $11.5-59.4 \%$ and $10.8-61.2 \%$ for TOC and DOC respectively (Fig. 2).

A significant increase in organic substance removal effectiveness was found after bed replacement, which confirms the partial exhaustion of bed exhaustion potential before the replacement. On the other hand, the successive decrease in organic substance removal effectiveness in the first two months after bed replacement may be explained by bed break-in and the development of biofilm on bed grains. After this time period, a certain equilibrium developed between adsorption and biodegradation. 
Table 3. Ranges of water quality indicators before and after absorption.

\begin{tabular}{|c|c|c|c|}
\hline Indicator & Unit & $\begin{array}{c}\text { Before } \\
\text { Adsorption }\end{array}$ & $\begin{array}{c}\text { After } \\
\text { Adsorption }\end{array}$ \\
\hline $\mathrm{T}$ & ${ }^{\circ} \mathrm{C}$ & $6.70-23.30$ & $7.70-23.50$ \\
\hline $\mathrm{pH}$ & & $6.73-7.72$ & $6.65-7.60$ \\
\hline $\mathrm{Basicity}$ & $\mathrm{val} / \mathrm{m}^{3}$ & $2.00-3.50$ & $2.00-3.50$ \\
\hline $\mathrm{Mt}$ & $\mathrm{NTU}$ & $0.10-0.80$ & $0.00-0.60$ \\
\hline $\mathrm{B}$ & $\mathrm{g} / \mathrm{m}^{3}$ & $4.60-7.60$ & $0.40-4.30$ \\
\hline $\mathrm{UV}_{254}$ & $\mathrm{M}^{3}$ & $5.94-8.38$ & $0.44-5.58$ \\
\hline $\mathrm{UV}_{272}$ & $\mathrm{M}^{2}$ & $4.91-6.87$ & $0.36-4.53$ \\
\hline $\mathrm{TOC}^{2}$ & $\mathrm{gC}^{3} \mathrm{~m}^{3}$ & $2.90-4.60$ & $1.82-4.77$ \\
\hline $\mathrm{DOC}^{3}$ & $\mathrm{gC}^{3}$ & $2.86-4.33$ & $1.63-4.23$ \\
\hline $\mathrm{NO}_{3}{ }^{-}$ & $\mathrm{gNO}_{3}{ }^{-} / \mathrm{m}^{3}$ & $2.68-21.66$ & $2.86-21.75$ \\
\hline $\mathrm{NO}_{2}^{-}$ & $\mathrm{gNO}_{2}{ }^{-} / \mathrm{m}^{3}$ & $0.00-0.03$ & $0.00-0.03$ \\
\hline $\mathrm{NH}_{4}{ }^{+}$ & $\mathrm{gNH}_{4}{ }^{+} / \mathrm{m}^{3}$ & $0.00-0.07$ & $0.00-0.07$ \\
\hline $\mathrm{Cl}^{-}$ & $\mathrm{gCl}^{-} / \mathrm{m}^{3}$ & $24.30-55.90$ & $24.00-55.90$ \\
\hline $\mathrm{SO}_{4}^{-2}$ & $\mathrm{gSO}_{4}^{-2} / \mathrm{m}^{3}$ & $63.80-129.90$ & $63.80-130.20$ \\
\hline $\mathrm{PO}_{4}^{-3}$ & $\mathrm{gPO}_{4}^{-3} / \mathrm{m}^{3}$ & $0.00-0.04$ & $0.00-0.03$ \\
\hline $\mathrm{SUVA}^{3}$ & $\mathrm{~m}^{2} / \mathrm{g}$ & $1.65-2.29$ & $0.46-1.93$ \\
\hline
\end{tabular}

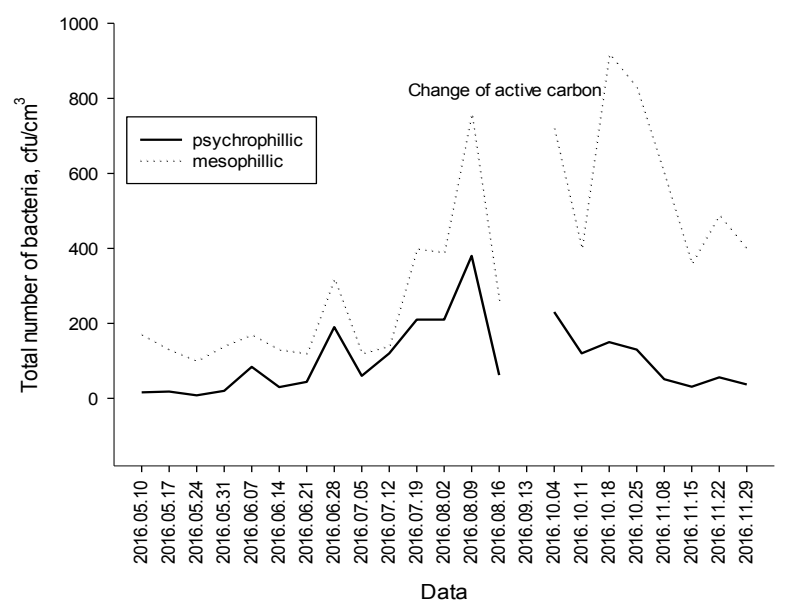

Fig. 1. Variation in numbers of psychrophillic and mesophillic bacteria in water supplying adsorption beds.

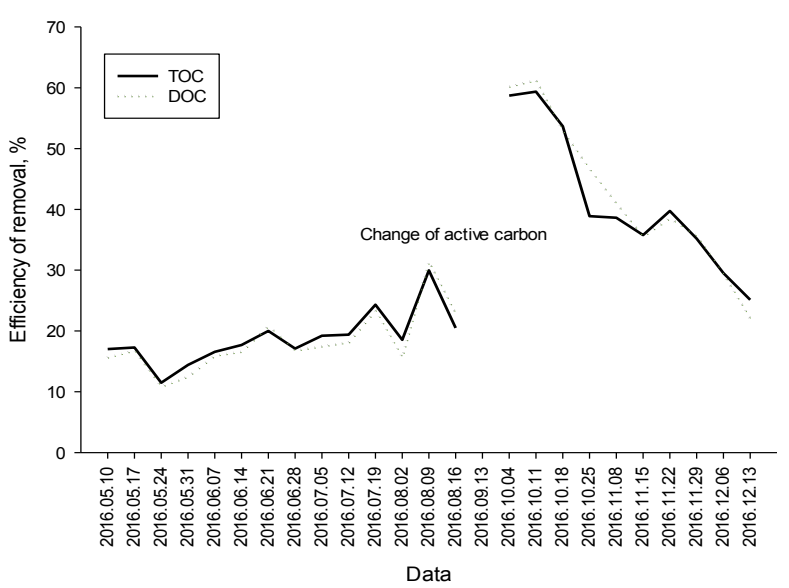

Fig. 2. Total and dissolved organic carbon removal effectiveness during adsorption.

The following nearly constant effectiveness corresponds to that obtained in bends before replacement. It is likely that the reduction in adsorption effectiveness was accompanied by an increase of the degree of biodegradation, which ensured a continued constant process effectiveness for a long time period. This points to the fact that exhaustion of the beds did not take place in any of the beds, which is also confirmed by the iodine number of the replaced bed.

The obtained effectiveness in reducing TOC and DOC concentrations before bed replacement testifies therefore to the simultaneous nature of adsorption and biodegradation. The biological effectiveness of the adsorption beds before replacement is also testified to by the simultaneous removal in ammonia ion content and phosphate concentrations, i.e. non-organic food substrates for heterotrophic bacteria [19]. The effectiveness in removing ammonia ions was in the range of $7.1-75.0 \%$ and was accompanied by an increase in nitrates (found in the time period before bed replacement), which may point to a process of nitrification in the absorption bed. This hypothesis is confirmed by the presence of dissolved in oxygen in water entering the beds, and the decrease in its concentration in the range 1.12-1.72 $\mathrm{gO}_{2} / \mathrm{m}^{3}$ during flow through the bed. The nitrification process was also aided by the small variation in water flow through the system, yielding stable bed operating conditions.

After bed replacement, however, a significant increase in phosphate concentrations was found, as phosphates were probably flushed out from fresh activated carbon. With respect to non-organic nitrogen compounds, no general trend was found, which may point to their simultaneous use by microorganisms and their release from activated carbon. Such a lack of clear decrease or increase is the result of these mechanisms. After bed replacement, apart from an increase in phosphate concentration, a significant increase of the total number $\mathrm{o}$ mesophillic and 
psychrophillic bacteria was found, being in the ranges of $799-28944 \mathrm{cfu} / \mathrm{cm}^{3}$ and $1170-44510 \mathrm{cfu} / \mathrm{cm}^{3}$ respectively.

It was found that during the study period, the organic substance removal effectiveness was proportional to their content in water reaching the adsorption beds. (Fig. 3). This indicates that the variability in organic substances levels in water entering adsorption beds and the source water contamination levels has a significant impact on effective organic substance elimination.

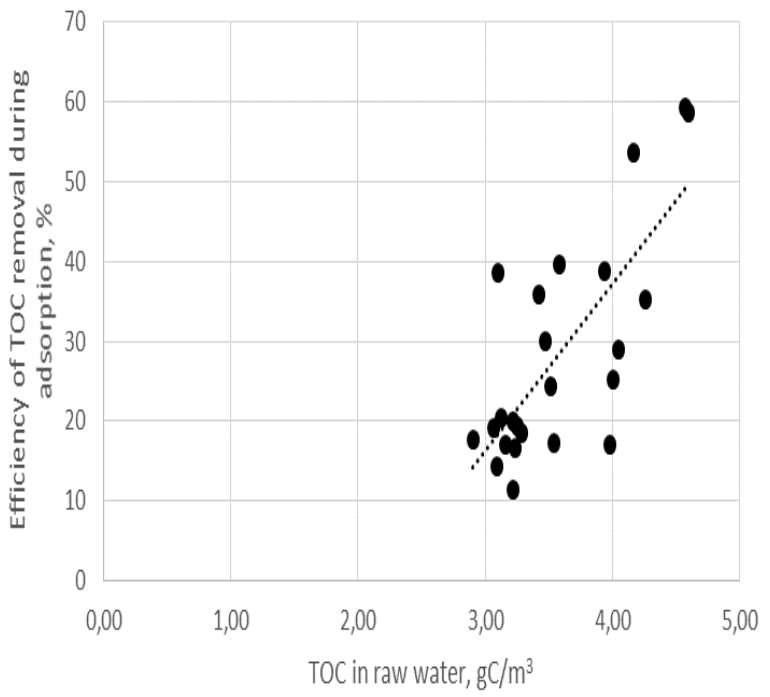

Fig. 3. Effect of organic substance content in raw water on their elimination during the adsorption process.

Among the removed organic substances, UV absorbing substances at wavelength of $254 \mathrm{~nm}$ and $272 \mathrm{~nm}$ dominated, corresponding to disinfection by-products. The effectiveness in removing dissolved organic carbon was nearly proportional to the effectiveness in decreasing UV absorbance at $254 \mathrm{~nm}$ and $272 \mathrm{~nm}$ (Fig. 4).

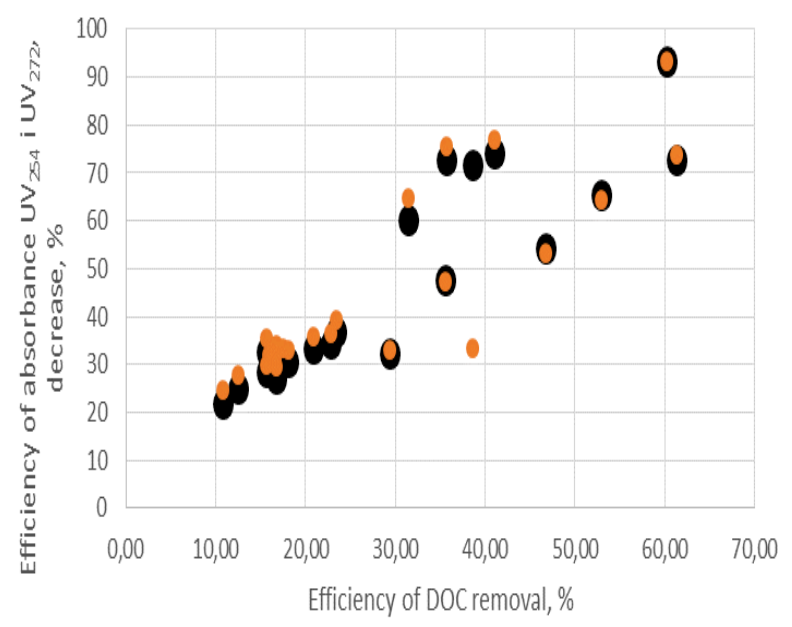

- UV254 U UV272

Fig. 4. Dependence of dissolved organic carbon removal and UV absorbance.
According to Korshin et al [20], these precursors exhibit a significantly larger correlation to absorbance at $272 \mathrm{~nm}$ than at $254 \mathrm{~nm}$. An effective elimination of chlorinated organic substance precursors regardless of the bed adsorption potential exhaustion ensures a significant limiting of risks associated with disinfection that is used after the adsorption process [17,21].

A consequence of the decrease in organic substance content during adsorption was a decrease in specific UV absorbance in all filtrate samples. This points to the fact the adsorption process removed organic substances of medium molecular mass, and to a lesser degree small organic substances.

Due to the small variability in system throughput, no unambiguous relationship was found between organic substance removal effectiveness and the water flow rate through the bed. Furthermore, no relationship was found between the temperature of water supplying the bed and the adsorption process effectiveness.

\section{Conclusions}

This study has shown:

1. An effective elimination of organic substances just after filtration bed replacement and achieving an equilibrium between adsorption and biodegradation after two months of operation.

2. Biological activity of filtration beds before replacement ensured the removal of not only organic substances but also non-organic food substrates.

3. In the biologically active adsorption bed nitrification took place, which may testify to biofilm stability on the surface of activated carbon. .

4. Among organic substances, those most effectively removed regardless of adsorption bed exhaustion, were chlorinated organic substance precursors absorbing UV radiation.

5. A slight increase in water-bed contact time has no effect on the effectiveness of the adsorption process.

This publication was made possible by the National Center for Research and Development grant (PBS3/B9/44/2015) "Research on effectiveness of new water treatment technology as a step towards a shift in thinking about water utility sector" (WODTECH), and thanks to involvement of both project consortium members (Wrocław Municipal Waterworks and Drainage Company and Wrockaw University of Science and Technology)

\section{References}

1. W. Wang, L. Ho, D.M. Lewis, J.D. Brookes, G. Newcombe, Water Res. 17, 41 (2007)

2. J. Kim, B. Kang, Water Res. 1/2, 42 (2008)

3. M. Kłos, J. Gumińska, Ochr. Sr. 31, 3 (2009) 
4. H. Ødegaard, S. Østerhus, E. Melin, B. Eikebrokk, Drinking Water Eng. Sci. 1, 3 (2010)

5. T.D. Lekkas, K.G. Babi, K.M. Koumenides, C. A. Makri, D.T. Lekkas, A.D. Nikolaou, Global Nest J. 11, 3 (2009)

6. C.O. Lee, K.J. Howe, B.M. Thomson, Water Res. 4, $46(2012)$

7. J. Reungoat, M. Macova, B.I. Escher, S. Carswell, J.F. Mueller, J. Keller, Water Res. 2, 44 (2010)

8. F. Hammes, S. Meylan, E. Salhi, O. KÖster, T. Egli, U. von Gunten, Water Res. 7, 41 (2007).

9. Y. Luo, W. Guo, H.H. Ngo, L.D. Nghiem, F.I. Hai, J. Zhang, X.C. Wang, Sci. Total Environ. 1, 473 (2014)

10. T. Urase, T. Kikuta, Water Res. 7, 39 (2005)

11. K. Ignatowicz, J. Hazard. Mater. 1, 169 (2009)

12. R.I. Yousef, B. El-Eswed, H. Ala'a, Chem. Eng. J. 3, $171(2011)$

13. C.Y. Cao, J. Qu, W. S. Yan, J.F. Zhu, Z.Y. Wu, W.G. Song, Langmuir. 28, 9 (2012)

14. H. Wang, L. Ho, D.M. Lewis, J.D. Brookes, G. Newcombe, Water Res. 18, 41 (2007)

15. E.S. Melin, H. Ødegaard, Water Res. 18, 34 (2000)

16. A. Pruss, A. Maciołek, I. Lasocka-Gomuła, Ochr. Sr. 31, 4 (2009)

17. I. Zimoch, B. Kotlarczyk, A. Sołtysik Ochr. Sr. 29, 3 (2007)

http://www.os.not.pl/docs/czasopismo/2007/Zimoch_3 -2007.pdf

18. T. Karanfil, M.A. Schlautman, I. Erdogan, AWWA J. 12, 94 (2002)

19. E.C. Wert, J.J. Neemann, D.J. Rexing, R.E. Zegers, Water Res. 1/2, 42 (2008)

20. G.V. Korshin, W.W. Wu, M.M. Benjamin, O. Hemingway, Water Res. 13, 36 (2002)

21. I. Zimoch, Ochr. Sr. 33, 3 (2011)

http://www.os.not.pl/docs/czasopismo/2011/3-

2011/Zimoch_3-2011.pdf 